\title{
Molecular Analysis of an Antibiotic Resistance Plasmid, pAV5, and Its Derivative Plasmids in Acinetobacter calcoaceticus
}

\author{
By MARK DIVERS $\dagger$ P. LYNNE CRAVEN $\ddagger$ AND ALAN VIVIAN $\ddagger *$ \\ School of Biological Sciences and Environmental Health, Thames Polytechnic, Wellington Street, \\ London SE18 6PF, UK
}

(Received 2 May 1985; revised 22 July 1985)

\begin{abstract}
The non-conjugative plasmid pAV5 specifies resistance to kanamycin/neomycin $\left(\mathrm{Km}^{\mathbf{R}}\right)$ and tetracycline $\left(\mathrm{Tc}^{\mathbf{R}}\right)$. Physical evidence is presented to show that $\mathrm{pAV} 5$ gives rise to two plasmids, pAV51 $\left(\mathrm{Km}^{\mathrm{R}}\right)$ and pAV52 $\left(\mathrm{Tc}^{\mathbf{R}}\right)$, which are formed by deletion of apparently non-overlapping segments of pAV5. Expression of $\mathrm{Tc}^{\mathbf{R}}$ has been obtained in Escherichia coli and is associated with a $1.9 \mathrm{~kb}$ HindIII fragment found in pAV5 and in pAV52. Expression of $\mathrm{Km}^{\mathrm{R}}$ has been obtained in $E$. coli and is associated with a $1.3 \mathrm{~kb} P$ st I fragment found in pAV5 and pAV51. Evidence is presented that the $\mathrm{Km}^{\mathrm{R}}$ gene is flanked by inverted repeat sequences and is therefore tentatively identified as a transposon, designated $\mathrm{Tn} 4411$. The $\mathrm{Km}^{\mathrm{R}}$ gene specifies an aminoglycoside $3^{\prime}$-phosphotransferase-type I (APH(3')-I) enzyme.
\end{abstract}

\section{INTRODUCTION}

The Gram-negative, non-fermentative bacterium Acinetobacter calcoaceticus resembles Pseudomonas aeruginosa in several aspects of its biology, not the least of which is its important clinical role as an opportunistic pathogen, frequently exhibiting exceptionally varied and comprehensive resistance to antibiotics (French et al., 1980; Dibb et al., 1983). Plasmidmediated resistance, however, is apparently uncommon (French et al., 1980; Goldstein et al., 1983), although a strain, JC17, isolated from a hospital in Pretoria, South Africa, has been shown to harbour a conjugative plasmid (pAV1) and a non-conjugative plasmid (pAV5) which both specify antibiotic resistance (Hinchliffe $e t$ al., 1980) and have been transferred to several wild-type strains of $A$. calcoaceticus, pAV1 serving to mobilize transfer of pAV5. The resistance determinants carried by pAV5 occasionally segregated on transfer, resulting in the apparent formation of independent, compatible replicons: pAV51 which specifies resistance to kanamycin and neomycin $\left(\mathrm{Km}^{\mathbf{R}}\right)$ and pAV52 which specifies resistance to tetracycline $\left(\mathrm{Tc}^{\mathbf{R}}\right)$ (Divers et al., 1984).

This report describes the isolation of plasmid DNA from strains of $A$. calcoaceticus harbouring pAV5, pAV51 and pAV52, and its characterization by restriction mapping, cloning and electron microscopy. The results indicate that pAV51 and pAV52 are deletion derivatives of pAV5. They also suggest that the $\mathrm{Km}^{\mathbf{R}}$ gene is flanked by inverted repeat sequences in inverse orientation and that one or both of these sequences may be responsible for generating the deletions giving rise to pAV51 and pAV52.

\section{METHODS}

Bacterial strains, plasmids and phage. These are listed in Table 1.

Media and culture conditions. These were as described previously for $A$. calcoaceticus (Hinchliffe \& Vivian, 1980 a). Escherichia coli was cultured on L-broth or L-agar at $37^{\circ} \mathrm{C}$.

$\uparrow$ Present address: Ciba Geigy AG, K681.1.08 CH-4002 Basel, Switzerland.

‡ Present address: Science Department, Bristol Polytechnic, Coldharbour Lane, Frenchay, Bristol BS16 1QY. 
Table 1. Bacteria, plasmids and phage DNA

Strain

Relevant characteristics

Source

\begin{tabular}{|c|c|}
\hline \multicolumn{2}{|c|}{ Acinetobacter calcoaceticus } \\
\hline $\mathrm{JC} 17$ & pAVl pAV5 \\
\hline EBF $65 / 65$ & Wild-type \\
\hline $\mathrm{C} 4141$ & his-1 trp-2 rif-1 pAV1 pAV5 \\
\hline BD413 & $\begin{array}{l}\text { Wild-type: all derivative strains } \\
\text { prefixed } C 9\end{array}$ \\
\hline C91 & $\mathrm{Ura}^{-} \mathrm{Rif}^{\mathrm{R}} \operatorname{Str}^{\mathrm{R}}$ \\
\hline C915 & Ura $^{-}$Rif $^{R} \operatorname{Str}^{R}$ pAV52 \\
\hline C916 & $\mathrm{Ura}^{-}$Rif $^{\mathrm{R}} \mathrm{Str}^{\mathrm{R}}$ pAV1 pAV51 \\
\hline $\mathrm{C} 917$ & $\mathrm{Ura}^{-} \mathrm{Rif}^{\mathrm{R}} \mathrm{Str}^{\mathrm{R}}$ pAV5 \\
\hline \multicolumn{2}{|l|}{ Escherichia coli } \\
\hline HB101 & $\mathrm{F}^{-} \mathrm{Pro}^{-} \mathrm{Leu}^{-} \mathrm{RecA}^{-}$ \\
\hline $5 K-1$ & $\begin{array}{l}\text { thr-1 leu-6 thi-1 tonA2I hsdM hsdR } \\
\text { supE44 } \mathrm{Rif}^{\mathrm{R}}\end{array}$ \\
\hline \multicolumn{2}{|l|}{ Plasmids } \\
\hline pAV1 & $\mathrm{Su}^{\mathrm{R}}$ conjugative \\
\hline pAV5 & $\mathrm{Km}^{\mathrm{R}} / \mathrm{Nm}^{\mathrm{R}} \mathrm{Tc}^{\mathrm{R}}$ non-conjugative \\
\hline pAV51 & $\mathrm{Km}^{\mathrm{R}} / \mathrm{Nm}^{\mathrm{R}}$ non-conjugative \\
\hline pAV52 & $\mathrm{Tc}^{\mathrm{R}}$ non-conjugative \\
\hline pML21 & Used as source of Tn903 \\
\hline pBR328 & $\mathrm{Ap}^{\mathrm{R}} \mathrm{Cm}^{\mathrm{R}} \mathrm{Tc}^{\mathrm{R}}$ \\
\hline pUC8 & $\mathrm{Ap}^{\mathrm{R}}$ \\
\hline pAT153 & Used as size standard ( $3656 \mathrm{bp}$ ) \\
\hline \multicolumn{2}{|l|}{ Phage DNA } \\
\hline$\phi \times 174$ & Used as size standard (5386 bp) \\
\hline PM2 & Used as size standard $(9.6 \mathrm{~kb})$ \\
\hline$\lambda$ & $\begin{array}{l}\text { Used as size standard for } \\
\text { restriction analysis }\end{array}$ \\
\hline
\end{tabular}

Hinchliffe \& Vivian (1980a)

Hinchliffe \& Vivian (1980b)

Hinchliffe \& Vivian $(1980 b)$

Divers et al. (1984)

Divers et al. (1984)

Divers et al. (1984)

Divers et al. (1984)

Divers et al. (1984)

Dr P. J. Greenaway, PHLS CAMR,

Porton Down, UK

Spontaneous Rif ${ }^{\mathrm{R}}$ mutant of $5 \mathrm{~K}^{--}$(Dr P. H. Williams, University of Leicester, UK)

Hinchliffe \& Vivian (1980a)

Divers et al. (1984)

Divers et al. (1984)

Divers et al. (1984)

Hershfield et al. (1976)

Soberon et al. (1980)

Vieira \& Messing (1982)

Twigg \& Sherratt (1980)

Sanger et al. (1978)

Stuber \& Bujard (1977)

Daniels et al. (1980)

Antibiotics. These were obtained from Sigma and were added to media as freshly prepared solutions at the following final concentrations $\left(\mu \mathrm{g} \mathrm{m}^{-1}\right)$ : for $A$. calcoaceticus, kanamycin sulphate, 50 ; tetracycline hydrochloride, 5 ; for $E$. coli, sodium ampicillin, 50; kanamycin sulphate, 50; tetracycline hydrochloride, 20 (except pAV5 Tc ${ }^{\mathbf{R}}$ gene, 10); for pUC8 and clones derived from it, sodium ampicillin, 125.

Filter matings. These were as described by Towner \& Vivian (1976).

Isolation and purification of plasmid DNA. The method of Clewell \& Helinski (1969) was used; for amplifiable plasmids in $E$. coli, spectinomycin $\left(300 \mu \mathrm{g} \mathrm{ml}^{-1}\right)$ was added to cultures towards the end of the exponential phase to amplify plasmid DNA. Yields of DNA were estimated using a Beckman DU-8 spectrophotometer, assuming an absorbance of 1.0 at $260 \mathrm{~nm}$ for a solution of DNA $\left(50 \mu \mathrm{g} \mathrm{ml}^{-1}\right)$.

Restriction endonucleases and T4 DNA ligase. These were obtained from BRL and Boehringer, respectively, and used according to the conditions recommended by the supplier.

Cloning of $p A V 5$. Purified pAV5 DNA was digested with appropriate restriction endonucleases and ligated into similarly digested pBR328 DNA (Soberon et al,, 1980). Transformation of $E$. coli with the resulting ligation mixtures enabled the identification of recombinant clones (Fig. 1) by insertional inactivation of the vector resistance genes, colony hybridization and restriction analysis.

Agarose gel electrophoresis of DNA from single colonies. This was as described previously (Divers et al., 1984). Purified DNA preparations were examined on a transilluminator after staining with ethidium bromide as described by Maniatis et al. (1982).

Extraction of DNA from agarose. Specific restriction fragments were recovered after electrophoretic separation by the following procedure (P. J. Greenaway, pers. comm.). The position of the required fragment was identified by visualization on a transilluminator and a small block of agarose containing this band was cut out of the gel. The block was placed in a syringe $(2 \mathrm{ml})$ inside which two sterile discs of Whatman $\mathrm{GF} / \mathrm{C}$ paper had been positioned over the nozzle outlet. The reassembled syringe was kept at $-70^{\circ} \mathrm{C}$ for $30 \mathrm{~min}$ and then completely thawed at room temperature. The agarose was gently squeezed and liquid collected until the agarose started to burst through the GF/C paper. DNA was purified by phenol (redistilled, equilibrated with TE buffer) extraction, ether extraction and ethanol precipitation (Maniatis et al., 1982).

Hybridization studies. ${ }^{32}$ P-labelled DNA was prepared by nick translation (Rigby et al., 1977). Restriction enzyme-digested DNA was transferred from agarose gels to nitrocellulose by Southern blotting. DNA 
hybridizations were done in $50 \%(\mathrm{w} / \mathrm{v})$ formamide in $2 \times \mathrm{SSC}$ solution $(1 \times \mathrm{SSC}$ is $0 \cdot 15 \mathrm{M}-\mathrm{NaCl}, 0 \cdot 15 \mathrm{M}$-sodium citrate), and incubated $\left(16\right.$ to $\left.48 \mathrm{~h}, 37^{\circ} \mathrm{C}\right)$ with occasional agitation. Colony hybridization was done as described by Grunstein \& Hogness (1975). Autoradiography was done at $-70^{\circ} \mathrm{C}$ with Kodak XRP-5 X-ray film.

Bacterial transformation. For A. calcoaceticus BD413, the procedure of Cruze et al. (1979) was used with recipient cells cultured in L-broth $(50 \mathrm{ml})$ supplemented with $50 \%(\mathrm{w} / \mathrm{v})$ glucose $(0.5 \mathrm{ml})$. For $E$. coli, the method of Kushner (1978) was used.

Electron microscopy. Denaturation-renaturation for the formation of intramolecular homoduplex structures was as follows. Denaturing solution $(25 \mu \mathrm{l} ; 1 \mathrm{M}-\mathrm{NaOH}, 0 \cdot 2 \mathrm{M}$-EDTA) was added to isolated restriction fragment DNA solution $(10 \mu \mathrm{l})$ previously purified on a Sepharose $2 \mathrm{~B}$ column. After $10 \mathrm{~min}$ at room temperature, the DNA was renatured by the addition of formamide $(25 \mu \mathrm{l})$ and $2 \mathrm{M}$-Tris/ $\mathrm{HCl} \mathrm{pH} 7 \cdot 2(2.5 \mu \mathrm{l})$, and incubated at $33^{\circ} \mathrm{C}$ for $5 \mathrm{~min}$. DNA was prepared by a cytochrome $c$ monolayer spreading technique similar to those described by Ferguson \& Davis (1978) and Brack (1981).

\section{RESULTS}

\section{Isolation of plasmids $p A V 5, p A V 51$ and $p A V 52$}

Divers et al. (1984) obtained strains of $A$. calcoaceticus possessing pAV5 (strain C917) and pAV52 (strain C915) as single plasmids, which facilitated their isolation in pure form. A third strain (C916) possessing pAV5I also harboured pAV1, but the latter plasmid was apparently largely excluded from preparations of plasmid DNA under the conditions used to isolate pAV51, presumably due to its larger size (approx. $135 \mathrm{~kb}$ ). The plasmid DNA species were used to transform $A$. calcoaceticus strain C91 (Table 1): $\mathrm{Km}^{\mathbf{R}}$ transformants were obtained only with pAV5 and pAV51 DNAs, and $\mathrm{Tc}^{\mathrm{R}}$ transformants only with pAV5 and pAV52 DNAs.

Attempts were made to transform $E$. coli $\mathrm{HB} 101$ with pAV5 DNA, but no transformants $\left(\mathrm{Km}^{\mathrm{R}}\right.$ or $\left.\mathrm{Tc}^{\mathrm{R}}\right)$ were obtained. Attempts were also made to transfer pAV5 from A. calcoaceticus to $E$. coli by conjugation using pAV1, a plasmid which mobilizes pAV5 between strains of A. calcoaceticus (Divers et al., 1984). No stable transconjugants were obtained from matings between $E$. coli $5 \mathrm{~K}-1$ and either $A$. calcoaceticus $\mathrm{JC} 17$ or $\mathrm{C} 4141$ (a strain derived from EBF 65/65; Table 1). These results support evidence from earlier experiments which indicated that pAV5 could not be maintained in E. coli (R. W. Hedges, pers. comm.).

\section{Restriction endonuclease analysis}

Four restriction enzymes, BamHI, EcoRI, HindIII and PstI, were used to digest pAV5, pAV51 and pAV52. The products were analysed by agarose gel electrophoresis. The best estimates of plasmid sizes based on these data are $23 \mathrm{~kb}$ (pAV5), $11.8 \mathrm{~kb}$ (pAV51) and $17.6 \mathrm{~kb}$ (pAV52). Some double digests were done using the same enzymes, but due to the complexity of the resulting restriction fragment patterns it was not possible to establish a restriction map from these experiments. However, comparison of the restriction patterns clearly demonstrated a relationship between the three plasmids.

\section{Electron microscopic size determination}

Plasmid sizes were also determined by electron microscopy using the size standards in Table 1. Mean estimates \pm one SD were for pAV5, $23.31 \pm 0.28 \mathrm{~kb}$ (26 molecules measured); pAV51, $11.68 \pm 0.09 \mathrm{~kb}(21) ; \mathrm{pAV} 52,17.05 \pm 0.21 \mathrm{~kb}(21)$. These values were in reasonably good agreement with those determined from restriction analysis.

\section{Cloning and derivation of a restriction map of pAV5}

Restriction fragments of pAV5 were cloned in E. coli HB101 by using the vector pBR328 (Soberon et al., 1980). Southern blotting and hybridization with ${ }^{32}$ P-labelled pAV5 DNA confirmed that the inserts were derived from pAV5. Eight different recombinant plasmids were chosen for further analysis (Fig. 1), which enabled the construction of a restriction map for pAV5 (Fig. 1). By assuming that similarities in the respective restriction patterns of pAV51 and pAV52 represented the presence of the same restriction fragments in pAV5, it was possible to infer maps for these two plasmids from the map of pAV5. This in turn showed that pAV51 and pAV52 were derived by deletion of specific fragments from pAV5 (Fig. 1). Four clones 

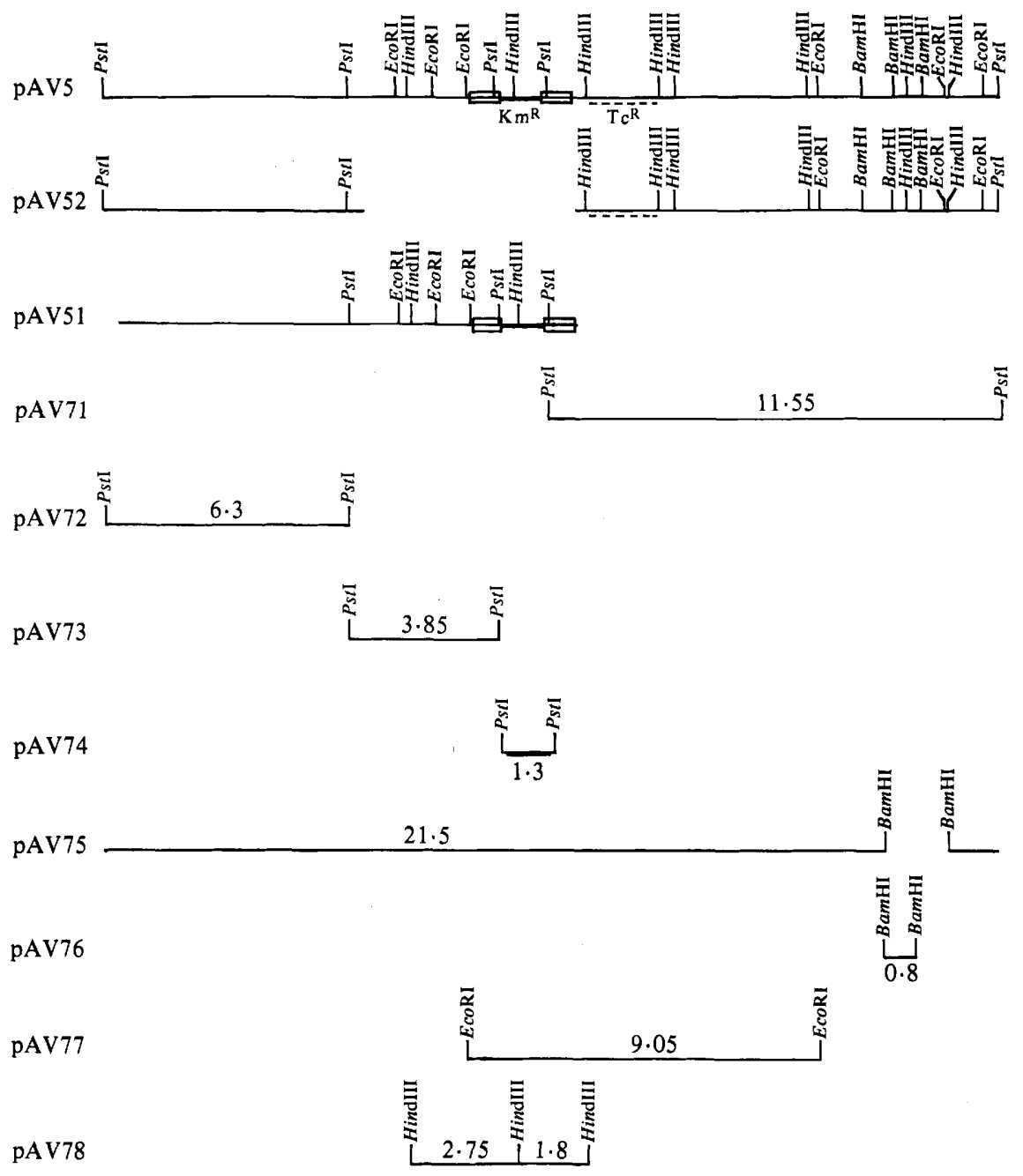

$$
\frac{1 \mathrm{~kb}}{1 \mathrm{k}}
$$

Fig. 1. Restriction endonuclease cleavage map of pAV5 and related plasmids. Restriction analysis and cloning were done as described in Methods. Maps for pAV5I and pAV52 are inferred from pAV5. Recombinant plasmids, designated pAV71 to pAV78, show the relevant fragments of pAV5, which were cloned in pBR328 (Soberon et al., 1980).

expressed resistance to kanamycin in E. coli. This located $\mathrm{Km}^{\mathrm{R}}$ on a $1.3 \mathrm{~kb}$ Pst I fragment, thus subsequently identifying its position on the restriction maps of pAV5 and pAV51 (Fig. 1).

\section{Nature of the $\mathrm{Km}^{R}$ determinant}

Attempts to transfer $\mathrm{Km}^{\mathrm{R}}$ from strains of $A$. calcoaceticus harbouring pAV5 (and pAV1) to $E$. coli resulted only in the rare acquisition of resistance. This suggested that the $\mathrm{Km}^{\mathrm{R}}$ determinant of pAV5 might be transposable. Similar observations with pAV5 in another laboratory using the IncI $_{\alpha}$ plasmid R64 as a mobilizing agent (Chopade et al., 1985) indicated that E. coli had acquired, at a very low frequency, $\mathrm{Km}^{\mathbf{R}}$, which was subsequently provisionally mapped to a chromosomal location close to trp, lac and pur markers ( $\mathbf{R}$. W. Hedges, pers. comm.).

In view of this possibility, it was of interest to examine whether pAV5 DNA exhibited stemloop structures under the electron microscope after denaturation-renaturation. The largest 


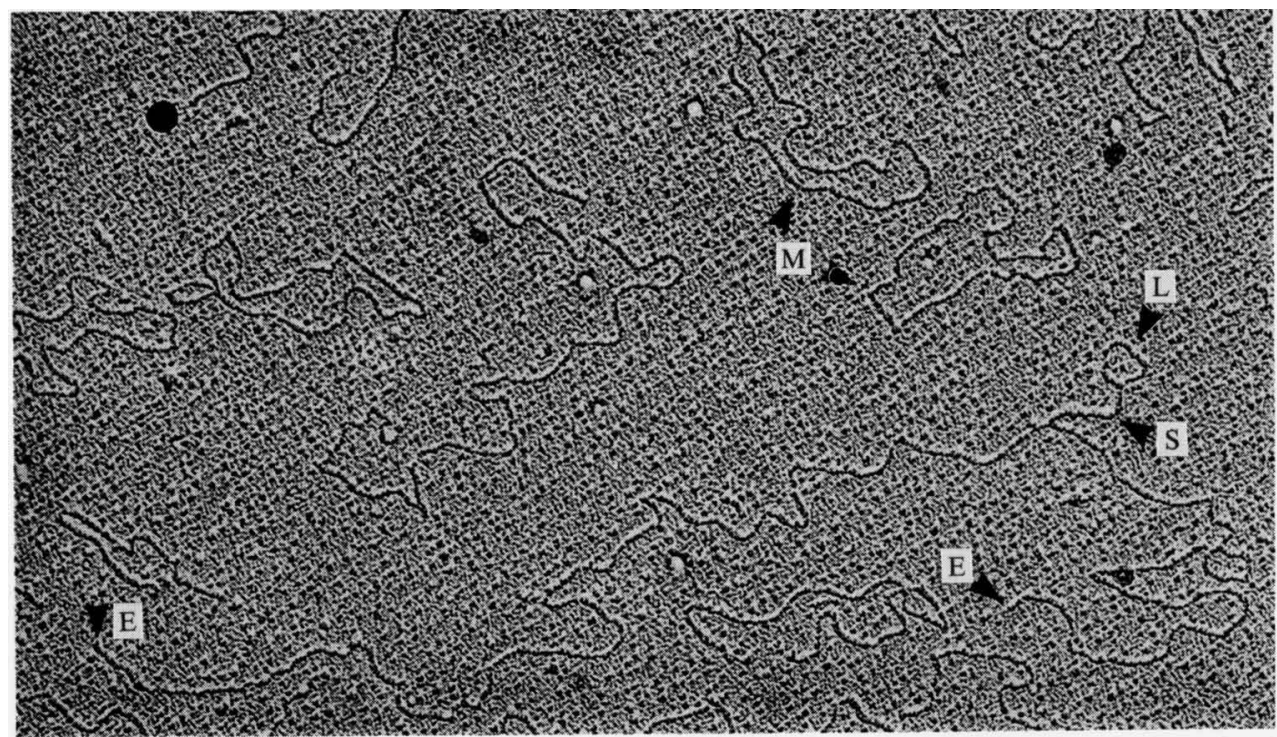

Fig. 2. Electron micrograph of pAV5 stem-loop structure. The largest BamHI fragment of pAV5 was denatured, renatured and prepared for electron microscopy as described in Methods. E, ends of singlestranded DNA; L, single-stranded loop; M, ФX174 DNA used as size standard (5386 bp); S, doublestranded stem.

Table 2. Size determination of denaturation-renaturation structure of the large BamHI fragment of pAV5 by electron microscopy

\begin{tabular}{lccr}
\multicolumn{1}{c}{ Feature observed } & $\begin{array}{c}\text { No. of structures } \\
\text { measured }\end{array}$ & Relative size* & $\begin{array}{c}\text { Absolute size } \\
(\mathrm{kb}) \dagger\end{array}$ \\
Stem & 28 & $0.15 \pm 0.003$ & $0.81 \pm 0.02$ \\
Loop & 28 & $0 \cdot 20 \pm 0.003$ & $1 \cdot 05 \pm 0.02$ \\
Long arm & 18 & $2 \cdot 01 \pm 0.02$ & $10.83 \pm 0 \cdot 11$ \\
Short arm & 19 & $1.32 \pm 0.01$ & $7 \cdot 10 \pm 0.08$ \\
Total length & 14 & $3.84 \pm 0.03$ & $20.68 \pm 0.14$ \\
Short arm and stem & 19 & $1.47 \pm 0.02$ & $7.93 \pm 0.08$
\end{tabular}

* Standard molecule used was $\phi \times 174$ (Table 1).

$\dagger$ Mean estimate \pm one SD.

BamHI fragment (present in pAV75) was chosen because, of all the cloned pAV5 fragments, it most comprehensively covered the $\mathrm{Km}^{\mathbf{R}}$ gene and, as a linear molecule, it permitted the location of visible structures with respect to its ends. The isolated Bam HI fragment was denatured and renatured under conditions favouring the formation of homoduplex structures and analysed by electron microscopy. The results (Fig. 2, Table 2) clearly demonstrated the presence of a stemloop structure. The overall size of the fragment $(20.68 \pm 0.15 \mathrm{~kb})$ was in good agreement with determinations by restriction analysis. The sizes of the stem and loop were $0.81 \pm 0.02 \mathrm{~kb}$ and $1.05 \pm 0.02 \mathrm{~kb}$ respectively. Furthermore, single-strand length measurements indicated that the loop coincided with the position of the $\mathrm{Km}^{\mathrm{R}}$ gene on the restriction map. These results therefore suggest that the $\mathrm{Km}^{\mathrm{R}}$ gene is flanked by inverted repeat sequences of approximately $0.81 \mathrm{~kb}$.

Previous experiments in another laboratory (J. Davies, pers. comm.) have demonstrated that cell extracts of the original host of pAV5, strain JC17, contain aminoglycoside 3'phosphotransferase-type I (APH (3')-I) activity. It therefore seems that this enzyme is specified by the pAV5 kanamycin resistance gene. Confirmation of this was provided by the following hybridization experiment. PstI digests of pAV5, pAV51 and pAV52 were transferred to nitrocellulose and hybridized with ${ }^{32}$ P-labelled pML21 DNA. This plasmid consists of 
fragments of plasmids ColE1 and R6-5 variously manipulated (Hershfield et al., 1976), and contains Tn903, the $\mathrm{Km}^{\mathrm{R}}$ gene of which codes for an APH(3')-I (Berg et al., 1978). The results were detected by autoradiography and showed that the probe hybridized only with the $1.3 \mathrm{~kb}$ PstI fragment present in pAV5 and pAV51 but not in pAV52. This fragment bears the entire $\mathrm{Km}^{\mathrm{R}}$ gene of pAV5 (see previous section) and presumably little more. No other fragments of these plasmids and none of pAV52 hybridized. This result demonstrated that the pML21 probe was sufficiently specific for the $\mathrm{Km}^{\mathrm{R}}$ gene, and indicated that there was little similarity between the insertion sequences of Tn903 (IS903; Grindley \& Joyce, 1980) and the inverted repeats flanking the pAV5 $\mathrm{Km}^{\mathrm{R}}$ gene, since these must extend into the neighbouring PstI fragments, which did not hybridize.

\section{Mapping of the $T c^{R}$ determinant}

Purified DNA from pAV71 (Fig. 1) was digested with HindIII and subcloned in pUC8. A cloned designated pAV711 contained a $1.9 \mathrm{~kb}$ HindIII insert and expressed resistance to tetracycline $\left(10 \mu \mathrm{g} \mathrm{ml}^{-1}\right)$ in E. coli (Fig. 1).

\section{DISCUSSION}

The discovery and genetic analysis of pAV5 (Hinchliffe et al., 1980; Divers et al., 1984) revealed an interesting plasmid capable of undergoing phenotypic segregation of its two antibiotic resistance markers, a behaviour which was originally interpreted as physical dissociation of pAV5 into two constituent replicons. However, the molecular basis of these events was not then clearly understood; interpretations were based mainly on genetic evidence alone, and reliable physical evidence was not available. The physical analysis described here provides an insight into the structure of pAV5 and a clearer understanding of its behaviour. The existence and identity of plasmids pAV51 and pAV52 derived from pAV5 are confirmed physically and reliable estimates of their sizes (11.8, 17.6 and $23.0 \mathrm{~kb}$ respectively) have been obtained by restriction analysis and electron microscopy. Comparative restriction analysis, restriction mapping and location of the $\mathrm{Km}^{\mathrm{R}}$ and $\mathrm{Tc}^{\mathrm{R}}$ genes, facilitated by cloning of $\mathrm{pAV} 5$ fragments in $E$. coli (in which both resistance genes are expressed), indicate that the formation of plasmids pAV51 and pAV52 occurred by deletion of specific segments of pAV5. Furthermore, each of the two deleted segments has one terminus close to the $\mathrm{Km}^{\mathrm{R}}$ gene. Electron microscopy of homoduplex structures revealed the presence of $0.81 \mathrm{~kb}$ inverted repeat sequences flanking this gene, and some (albeit limited) genetic evidence suggests that the resistance marker is transposable. Although unequivocal genetic evidence is not yet available, it is proposed that the inverted repeats of pAV5 are insertion sequences and that one or both are responsible for the formation of pAV51 and pAV52 by generating the observed deletions from its borders. It would follow from this that, together with the $\mathrm{Km}^{\mathrm{R}}$ gene, these sequences might act as a transposon (provisionally designated Tn4411) on pAV5, of the composite type (Kleckner, 1981), with its insertion sequences in inverted orientations. The pAV5 kanamycin resistance gene codes for an APH( $\left.3^{\prime}\right)$-I enzyme.

It is not yet known whether the breakdown of pAV5 always results in the formation of either pAV51 or pAV52 or whether further derivatives can be formed (i.e. whether the deletions are specific or variable) since only one pair of pAV5 derivatives was studied. In this respect it is interesting to note the presence of a PstI site close to the distal termini (those furthest from the inverted repeats) of each deleted segment, as well as in the inverted repeat itself (see Fig. 1). Maybe they indicate some further homology between the regions which possibly might represent favoured target sites for specific deletions.

Two reports have invoked the presence of chromosomally located antibiotic resistance transposons in Acinetobacter (Shimizu et al., 1981; Devaud et al., 1982). In both cases antibiotic resistance phenotypes were non-self-transmissible and apparently not associated with plasmids, but could be mobilized to other strains by use of the conjugative plasmid RP4. The RP4 underwent size increases concomitant with mobilization, which were proposed to be due to transposition of resistance-mediating sequences from the host chromosome to RP4. In one of 
these cases (Devaud et al., 1982), evidence was also obtained against the possibility that the RP4-borne Tn3 had mediated the phenomenon.

It is now clear from a number of reports that clinically significant antibiotic resistance in Acinetobacter can be mediated by plasmids (Hinchliffe \& Vivian, 1980 $a$; Murray \& Moellering, 1980; Goldstein et al., 1983; Divers et al., 1984) and possibly transposons (this study; Shimizu et al., 1981; Devaud et al., 1982); this conclusion is hardly surprising for a Gram-negative, clinically prevalent, opportunistic pathogen. However, the number of such reports is small, and yet clinical isolates of Acinetobacter often exhibit particularly comprehensive antibiotic resistance (Vivian et al., 1981). The suggestion that clinically significant antibiotic resistance may be mediated by chromosomally located transposons is therefore an interesting possibility to consider for Acinetobacter.

Few plasmids in Acinetobacter have been subjected to detailed physical analysis. An important factor in this study was the use as a host for pAV5, pAV51 and pAV52 of strain BD413 (designated C9 here), which is not only naturally and highly competent for transformation (Cruze et al., 1979), but is also apparently free of indigenous plasmids (results not shown). An obstacle to previous attempts at physical analysis of pAV5 was the presence of several indigenous plasmids in the strains in which pAV5 was characterized genetically. The cloning of pAV5 fragments should permit further analysis to identify, for instance, sequences involved in replication and mobilization. An open question remains over the apparent compatibility of plasmids pAV51 and pAV52 for which genetic evidence exists (Divers et al., 1984); maybe pAV5 possesses two different incompatibility properties which segregate with the resistance markers. The work described here may also provide a basis for the development of cloning vectors suitable for use in Acinetobacter. This together with strain BD413 would have potential as a useful host-vector system for genetic manipulation in Acinetobacter.

The authors are grateful to Dr J. Davies and Dr R. W. Hedges for permission to quote their unpublished results; to Dr D. Kinchington for generous help with electron microscopy; and to Veronica Grover for excellent and cheerful technical assistance. We are indebted to Dr P. J. Greenaway for kind and considerable help in providing laboratory space and for invaluable guidance and advice. This work was supported by a project grant to A.V. from the Medical Research Council.

\section{REFERENCES}

Berg, D. E., Jorgensen, R. \& Davies, J. (1978). Transposable kanamycin-neomycin resistance determinants. In Microbiology - 1978, pp. 13-15. Edited by D. Schlessinger. Washington: American Society for Microbiology.

Brack, C. (1981). DNA electron microscopy. Critical Reriews in Biochemistry 10, 114-169.

Chopade, B. A., Wise, P. J. \& Towner, K. J. (1985). Plasmid transfer and behaviour in Acinetobacter calcoaceticus EBF 65/65. Journal of General Microbiology 131, 2805-2811.

Clewell, D. B. \& Helinski, D. R. (1969). Supercoiled circular protein-DNA complex in Escherichia coli: purification and induced conversion to an open circular DNA form. Proceedings of the National Academy of Sciences of the United States of America 62, $1159-1166$.

Cruze, J. A., Singer, J. T. \& Finnerty, W. R. (1979). Conditions for quantitative transformation in Acinetobacter calcoaceticus. Current Microbiology 3, 129-132.

Daniels, D. L., DE Wet, J. R. \& Blattner, F. R. (1980). New map of bacteriophage lambda DNA. Journal of Virology 33, 390-400.

Devaud, M., Kayser, F. H. \& BäChI, B. (1982). Transposon-mediated multiple antibiotic resistance in Acinetobacter strains. Antimicrobial Agents and Chemotherapy 22, 323-329.
DibB, W., K Jellvold, V. A. \& Digranes, A. (1983). Pseudomonas aeruginosa and Acinetobacter calcoaceticus in vitro susceptibility of 150 clinical isolates to $5 \beta$-lactam antibiotics and tobramycin. Chemotherapy 29, 332-336.

Divers, M., Hinchliffe, E. \& Vivian, A. (1984). Characterisation of an antibiotic resistance plasmid, pAV5 and its constituent replicons in Acinetobacter calcoaceticus. Genetical Research 44, 19.

Ferguson, J. \& Davis, R. W. (1978). Quantitative electron microscopy of nucleic acids. In Advanced Techniques in Biological Electron Microscopy, vol. II, pp. 123 171. Edited by J. K. Koehler. Berlin: Springer-Verlag.

French, G. L., Casewell, M. W., Roncoroni, A. J., Knight, S. I. \& Phillips, I. (1980). A hospital outbreak of antibiotic-resistant Acinetobacter anitratus: epidemiology and control. Journal of Hospital Infection 1, 125-131.

Goldstein, F. W., Labigne-Roussel, A., Gerbaud, G., Carlier, C., Collatz, E. \& Courvalin, P. (1983). Transferable plasmid-mediated antibiotic resistance in Acinetobacter. Plasmid 10, 138-147.

Grindley, N. D. F. \& Joyce, C. M. (1980). Genetic and DNA sequence analysis of the kanamycin resistance transposon $\operatorname{Tn} 903$. Proceedings of the National Academy of Sciences of the United States of America 77, 7176-7180. 
Grunstein, M. \& Hogness, D. S. (1975). Colony hybridisation: a method for the isolation of cloned DNAs that contain a specific gene. Proceedings of the National Academy of Sciences of the United States of America 72, 3961-3965.

Hershfield, V., Boyer, H. W., Chow, L. \& Helinski, D. R. (1976). Characterisation of a mini Col E1 plasmid. Journal of Bacteriology 126, 447-453.

Hinchliffe, E. \& Vivian, A. (1980a). Naturally occurring plasmids in Acinetobacter calcoaceticus : a $\mathrm{P}$ class $\mathrm{R}$ factor of restricted host range. Journal of General Microbiology 116, 75-80.

HiNCHLIFFE, E. \& Vivian, A. (1980b). Gene transfer in Acinetobacter calcoaceticus: fertility variants of the sex factor pAV1. Journal of General Microbiology 119, 117-122.

Hinchliffe, E., Nugent, M. E. \& Vivian, A. (1980). Naturally occurring plasmids in Acinetobacter calcoaceticus: pAV2, a plasmid which influences the fertility of the sex factor pAVI. Journal of General Microbiology 121, 411-418.

KLECKNER, N. (1981). Transposable genetic elements. Annual Review of Genetics 15, 341-404.

KUSHNER, S. R. (1978). An improved method for transformation of Escherichia coli with Col Elderived plasmids. In Genetic Engineering, pp. 17-23. Edited by H. B. Boyer \& S. Nicosia. Amsterdam: Elsevier.

Maniatis, T., Fritsch, E. F. \& SambrooK, J. (1982). Molecular Cloning: a Laboratory Manual. Cold Spring Harbor, NY: Cold Spring Harbor Laboratory.

Murray, B. E. \& Moellering, R. C., JR (1980). Evidence of plasmid-mediated production of aminoglycoside-modifying enzymes not previously described in Acinetobacter. Antimicrobial Agents and Chemotherapy 17, 30-36.
Rigby, P. W. J., Dieckmann, M., Rhodes, C. \& Berg, P. (1977). Labelling deoxyribonucleic acid to high specific activity in vitro by nick translation with DNA polymerase I. Journal of Molecular Biology 113, 237-251.

Sanger, F., Coulson, A. R., Friedman, T., Air, G. M., Barrell, B. G., Brown, N. L., Fiddes, J. C., Hutchinson, C. A., Slocombe, P. M. \& Smith, M. (1978). The nucleotide sequence of bacteriophage ФX174. Journal of Molecular Biology 125, 225-246.

Shimizu, S., Inoue, M. \& Mitsuhashi, S. (1981). Enzymatic adenylation of spectinomycin by Acinetobacter calcoaceticus subsp. anitratus. Journal of Antibiotics 34, 869-875.

Soberon, X., Covarrubias, L. \& Bolivar, F. (1980). Construction and characterisation of new cloning vehicles. IV. Deletion derivatives of pBR322 and pBR325. Gene 9, 287-305.

STUber, D. \& Bujard, H. (1977). Electron microscopy of DNA: determination of absolute molecular weight and linear density. Molecular and General Genetics 154, 299-303.

Towner, K. J. \& Vivian, A. (1976). RP4 fertility variants in Acinetobacter calcoaceticus. Genetical Research 28, 301-306.

Twigg, A. J. \& SherratT, D. J. (1980). Transcomplementable copy number mutants of plasmid $\mathrm{Col} \mathrm{El}$. Nature, London 283, 216-218.

Vieira, J. \& MESSING, J. (1982). The pUC plasmids, an M13 mp7-derived system for insertion mutagenesis and sequencing with synthetic universal primers. Gene 19, 259-268.

Vivian, A., Hinchliffe, E. \& Fewson, C. A. (1981). Acinetobacter calcoaceticus: some approaches to a problem. Journal of Hospital Infection 2, 199-203. 